\title{
Comparison of some functionalities of water soluble peptides derived from Turkish cow and goat milk Tulum cheeses during ripening
}

\author{
Hale İnci ÖZTÜRK ${ }^{1 *}$, Nihat AKIN ${ }^{1}$
}

\begin{abstract}
In this study, profiles and functional properties such as antioxidant, mineral binding, and antimicrobial activities of water-soluble peptides from Turkish goat milk Tulum cheese and cow milk Tulum cheese were examined during the ripening period. According to the results of RP-HPLC, the number of peptides increased as the ripening days progressed due to proteolysis. DPPH results indicated that the antioxidant activity of peptides increased as the ripening days progressed for these cheeses. However, the highest antioxidant activity of peptide extracts was found in goat milk Tulum cheese according to the DPPH assay. The highest Iron (II) binding activity of peptide extracts was determined in goat milk Tulum cheese on the 60th day. Peptide extracts obtained from goat milk Tulum cheese on the 90th day demonstrated an inhibitory effect against Salmonella typhimurium ATCC 14028.
\end{abstract}

Keywords: antimicrobial activity; antioxidant activity; bioactive peptide; mineral binding activity; Tulum cheese.

Practical Application: Determination of the effect of ripening time on the functional properties of water soluble peptides in Tulum cheese.

\section{Introduction}

A great number of cheese types are manufactured in certain geographic areas in the world and are consumed regionally in vast amounts. It was identified that more than 150 types of cheeses were found in Turkey (Akın, 2010). The most consumed and produced cheeses in Turkey are White pickled, Kaşar, and Tulum cheeses (Akin, 2010). According to the data of the Turkish Statistical Institute (2014), the annual production amount of Turkish Tulum cheese was 14,179 tonnes. Its production has increased considerably, and this growth in production has been kept up by a large number of cheese plants and mostly individual farmers in recent years.

Tulum cheese is one of the most famous Turkish cheeses. It has a granular or open texture; is semi-hard and white or cream in color; and has a buttery taste and tangy flavor. All these properties can change with the processing and ripening conditions. Tulum, which means "goat's skin bag" in Turkish, is made from goat's skin. The skin bag is utilized as a packaging material that has a small pore to control air and moisture transfer, thus improving microbial activity. Wild flora of raw milk is used in Tulum cheese production in order to obtain a traditional flavor, and therefore, starter cultures are not used. Fermentation starts from the drainage of whey and continues until the end of the pre-ripening period for about 15 days. In this fermentation process, salt is also added to about $2.5 \%$, and lactic acid is produced from lactose to control microbial growth. Thus, microorganisms that are selected under these conditions become dominant in the cheese media, and they start to produce some flavor components through glycolysis, proteolysis, and lipolysis. After pre-ripening, the Tulum cheese is transferred into a cooled room at about $2{ }^{\circ} \mathrm{C}-4{ }^{\circ} \mathrm{C}$ to control fermentation and enzymatic reaction.

Cheese ripening occurs as a result of various microbiological, biochemical, and metabolic processes (Farkye, 2004). Proteolysis, which occurs for as long as the cheese ripening, is the most complicated and significant biochemical process (Sousa et al., 2001). Large, medium-size, and small-size peptides, as well as free amino acids are formed in consequence of all proteolytic reactions that are brought about during ripening. Small-size peptides and amino acids caused by further proteolytic reaction are effective for the development of cheese flavor (McSweeney, 2004).

Bioactive peptides are special protein components consisting of 2 - 20 amino acids in length, and most of them demonstrate multifunctional features (Rutherfurd-Markwick \& Moughan, 2005). Most investigations (Korhonen \& Pihlanto, 2006; Pritchard et al., 2010) reported that bioactive peptides had a variety of physiological functions, such as immunomodulator, antithrombotic, antioxidative, mineral binding, antihypertensive, and antimicrobial effects.

Bioactive peptides are obtained from various dairy products, especially fermented foods such as cheese, kefir, and yoghurt. Owing to their high protein content, cheeses can be a natural source of peptides derived from milk proteins. A variety of proteolytic regulations and the effectiveness of proteolytic reactions during cheese ripening give rise to the formation of milk-derived peptides (Park et al., 2007). Secondary proteolysis that takes place in course of the ripening period may cause the occurrence of 
different peptides, and bio-functional activities occur depending on the ripening stage of the cheese (Haque et al., 2008).

Various enzymes, such as milk enzymes, rennet enzyme (chymosin), and microorganisms' or starter cultures' enzymes, found in cheese flora lead to the hydrolysis of casein $\left(\alpha_{\mathrm{s1}}^{-}, \alpha_{\mathrm{s}^{-}}\right.$, $\beta$ - and $\kappa$-caseins). Cheese may have rich bioactive peptides depending on the variety of the enzymes (Pihlanto, 2006). However, these enzymes and microflora are affected by heat treatment (Raynal-Ljutovac et al., 2007). The numbers, varieties, and functions of bioactive peptides that take place during the ripening period can be affected by this condition. Pisanu et al. (2015) determined that specific sequences, functions, and relative numbers of peptides differed significantly in raw and pasteurized sheep milk cheeses. The peptides occur through proteolysis during cheese ripening. Proteolysis in cheese is influenced by various parameters, including milk varieties used in the cheese production, enzymes such as plasmin from milk, chymosin from rennet, proteases from microbial flora or starter culture, cheese production process, acidity of the curd, salt to moisture proportion, and ripening time and temperature (Park \& Jin, 1998).

There are no investigations on the bioactive properties of peptides isolated from Turkish Tulum cheeses. Turkish Tulum cheese produced with raw milk was considered to be likely to present peptides with different amounts of bioactivities. In this study, Turkish Tulum cheeses produced with raw cow and goat milk were investigated to determine whether the peptides had antimicrobial, antioxidative, and mineral binding or chelating properties. The main objective of this research was to evaluate the effects of milk type and ripening periods on profiles and functional properties of water-soluble peptides isolated from Turkish Tulum cheeses. Cow and goat milk Tulum cheeses were compared in terms of potential bioactivity and abundance of peptides during the ripening period. Novel bio-functional dairy peptides, which are more active and functional than formerly studied bioactive peptides, were explored to determine which one provides better health advantages to consumers.

\section{Materials and methods}

\subsection{Experimental design and Turkish Tulum cheese making}

Goat and cow milk were fermented by its wild microflora. The calf rennet (Peyma-Chr. Hansen's Inc., Istanbul, Turkey) whose coagulation strength had 1:16000 MCU mL-1 was added at a level of $0.1 \%(\mathrm{v} / \mathrm{v})$, and coagulation took place at approximately $32 \pm 2{ }^{\circ} \mathrm{C}$, for about $60 \mathrm{~min}$. The coagulum was cut into pieces (about $3 \mathrm{~cm}^{3}$ ) and moved into cotton bags for whey drainage. Drainage was performed at room temperature for $12 \mathrm{~h}$, and the curd was put under pressure. After this stage, the curd was broken into pea-sized pieces, salted (3.5\%, w/w), and kept for 2 - 3 days at room temperature. Afterward, goat skin bags (the skin bags prepared and cleaned specially for this process) were tightly filled with salted and pea-sized curd at 2 different dairies (as cow milk cheese and goat milk cheese samples), and the samples packaged in goat skin were ripened for 120 days. Tulum cheeses were manufactured in duplicate, and the Tulum cheese samples were analyzed once in every $0,15,30,60,90$, and 120 days.

The Tulum cheeses were stored and ripened at $4{ }^{\circ} \mathrm{C}$ and were sampled from the different skin bags $(4 \mathrm{~kg})$ at each sampling time $(0,15,30,60,90$, and $120 \mathrm{~d})$ after the surface area (around 0.5 to $1.0 \mathrm{~cm}$ ) was thrown out.

\subsection{Evaluation of physicochemical properties of cheese milk}

In determination of the compositional characteristics of goat milk and cow milk samples used in cheese production, $\mathrm{pH}$, titratable acidity, dry matter, protein, fat and ash analyses were performed by using Kirk \& Sawyer (1991) method.

\subsection{Determination of physicochemical changes of Tulum cheeses during ripening period}

Dry matter content was examined by the gravimetric method, drying the sample to a constant weight at $103 \pm 2{ }^{\circ} \mathrm{C}$, following the International Dairy Federation (1982) standard. The Gerber-Van Gulik method using the cheese butyrometer (Funke Gerber, Germany) was utilized for examining fat content (International Organisation for Standardization, 2008). Ash was determined using the AOAC International method (Association of Official Analytical Chemists, 2002), whereas the Fox (1963) method was employed for determining Sodium chloride content. The $\mathrm{pH}$ meter WTW-315i (Germany) was used for $\mathrm{pH}$ determination. Titratable acidity was measured according to Richardson (1985). Total nitrogen (TN) in the Tulum cheeses was measured by the Kjeldahl method (Association of Official Analytical Chemists, 2000). The CR400 color measurement equipment (Minolta, China) was used for performing color analysis. According to CIELAB color scale, $\mathrm{L}^{*}, \mathrm{a}^{*}$, and $\mathrm{b}^{*}$ values were measured (Pinho et al., 2004). Water activity was measured using the AquaLab 3 TE (America) equipment (Lang \& Steinberg, 1980). All determinations were performed in duplicate.

\subsection{Extraction of Tulum cheese peptides}

Water-soluble extracts (WSEs) were obtained pursuant to the modified version of the method identified by Kuchroo \& Fox (1982). Tulum cheese samples ( $10 \mathrm{~g}$ ) were homogenized in $20 \mathrm{~mL}$ of deionized water for $10 \mathrm{~min}$ using a Stomacher (Mayo, homogeneous, Italy). The resulting homogenates were held at $4{ }^{\circ} \mathrm{C}$ for $1 \mathrm{~h}$ in a water bath (Memmert WB22, Germany). The insoluble materials were then separated by centrifugation (Nuve, NF800R, Germany) at $10,000 \times \mathrm{g}$ for $30 \mathrm{~min}$ at $4{ }^{\circ} \mathrm{C}$. Finally, the acquired supernatants were filtered by a membrane filter with $0.45 \mu \mathrm{m}$ diameter to remove residual suspended fat.

\subsection{Profiling of Tulum cheese peptides by RP-HPLC}

WSEs prepared from cheese samples during the ripening period were mixed $(1: 1, \mathrm{v} / \mathrm{v})$ with deionized water containing $0.2 \%$ trifluoroacetic acid, and filtered through a $0.45 \mu \mathrm{m}$ cellulose acetate filter. After filtration, samples were made ready for analysis, after being put into HPLC vials. To this end, the ThermoFinnigan Spectrasystem HPLC system was used. Chromatographic separation was done using a Phenomenex 
Jupiter C18 $\left(250 \mathrm{~mm} \times 4.6 \mathrm{~mm}, 5 \mu \mathrm{m}, 300 \mathrm{~A}^{\circ}\right)$ (Phenomenex, Torrance, CA, USA) RP-HPLC column. Mobile phase A was deionized water containing $0.1 \%$ trifluoroacetic acid (v/v), and mobile phase B was acetonitrile containing 0.1 trifluoroacetic acid (v/v). The measurements were made at $214 \mathrm{~nm}$. Finally, the gradient elution was performed (Topçu \& Saldamli, 2006).

\subsection{DPPH radical scavenging method for WSE}

The 1,1-diphenyl-2-picrylhydrazyl radical (DPPH) was performed by modifying the method of Bhandari et al. (2010) to examine antioxidant activity of water-soluble peptides. $0.1 \mathrm{~mL}$ of a sample, $0.9 \mathrm{~mL}$ tris hydrochloride $(\mathrm{HCl})$ buffer, and $2 \mathrm{~mL}$ of $0.1 \mathrm{mM}$ DPPH were added in spectrophotometer cuvettes. The cuvettes were then kept at room temperature for $30 \mathrm{~min}$ without light. Control value was determined by using distilled water (free extract). After $30 \mathrm{~min}$, the scavenging activity was monitored spectrophotometrically by the reduction in absorbance at $517 \mathrm{~nm}$. All experiments were carried out in triplicate. The results were calculated according to Equation 1.

Scavenging rate $(\%)=\left[1-\left(\right.\right.$ Absorbans $_{\text {sample }} /$ Absorbans $\left.\left._{\text {control }}\right)\right] \times 100$

\subsection{Iron (II) chelating/mineral binding activity}

In order to determine mineral binding activity, ferrous ion chelating ability of water-soluble extracts was examined. Ferrozine method with some modifications was used for the ferrous ion chelating ability (Tang et al., 2002). A volume of $2 \mathrm{~mL}$ of WSE was mixed with $0.1 \mathrm{~mL}$ of $2 \mathrm{mM}$ iron / ferrous (II) chloride and $0.2 \mathrm{~mL}$ of $5 \mathrm{mM}$ ferrozine (3-(2-pyridyl)-5,6bis(4-phenyl-sulfonic acid)-1,2,4- triazine) in spectrophotometer cuvettes. The cuvettes were then incubated in the dark at room temperature for $10 \mathrm{~min}$. After $10 \mathrm{~min}$, the absorbance was read at $562 \mathrm{~nm}$. All experiments were carried out in triplicate. Distilled water was used as a control. Chelating activity of sample mixture was calculated as Equation 2:

Chelating activity $(\%)=\left[1-\left(\right.\right.$ Absorbans $_{\text {sample }} /$ Absorbans $\left.\left._{\text {control }}\right)\right] \times 100$

\subsection{Antimicrobial activity}

The $\mathrm{pH}$ values of WSEs were adjusted to 4.6 by using $1 \mathrm{~N}$ $\mathrm{HCl}$ before antimicrobial activity analysis. A disk-diffusion assay was used with modifications to observe the antimicrobial activity of the WSEs (Bauer et al., 1966). Esherichia coli ATCC 25922, Listeria monocytogenes ATCC 7644, Staphylococcus auerus ATCC 25923, Clostridium perfringens ATCC 13124, Bacillus cereus ATCC 11778, and Salmonella typhimurium ATCC 14028 were used to determine antimicrobial activity. All cultures belonged to Provincial Control Laboratory in Konya, Turkey. Water-soluble extracts $(5,10$ and $20 \mu \mathrm{L})$ were moved into paper disks with $6 \mathrm{~mm}$ diameter (Whatman No. 1), and allowed to dry at room temperature in the laminar flow cabin. Deionized water was used as a negative control. Cultures of the different strains were activated using Brain-Heart broth. Two hundred microliters of cultures were added into $10 \mathrm{~mL}$ of Brain-Hearth broths and the cultures were incubated overnight at $37^{\circ} \mathrm{C}$. Thereafter, they were implemented at the surface of a petri dish containing the Brain-Heart agar medium, and dishes were allowed to dry in the laminar flow cabin. Whatman disks including water-soluble extracts were placed at the surface of inoculated petri dishes. Eventually, petri dishes were incubated at $37^{\circ} \mathrm{C}$ for $24 \mathrm{~h}-48 \mathrm{~h}$ to identify possible inhibition zones. In order to examine the antimicrobial activity, diameters of inhibition zones were measured.

\subsection{Statistical design}

The means of results were analyzed with repeated measures design and the means were compared through the Duncan's multiple range test with a confidence interval set at $95 \%$ (Minitab Inc., 1991).

\section{Result and discussion}

\subsection{Compositional characteristics of cheese milk}

The compositional characteristics of milk used in the cheese production are shown in Table 1. According to the results, titratable acidity and $\mathrm{pH}$ values of milk samples were between $0.14-0.16$ and $6.65-6.71$, respectively. Cow and goat milk were determined to be within the limits of literature in terms of dry matter, fat, protein and ash contents (Haenlein \& Caccese, 1984; Jenness, 1980).

\subsection{Physicochemical profile of Tulum cheeses during ripening period}

Physicochemical parameters of the Tulum cheeses at determined ripening period has been demonstrated in Table 2. It was examined that cow milk Tulum cheese had a higher fat content $(\mathrm{P}<0.01)$ due to the milk composition. The fat ratio did not differ in both cheeses during the ripening period. Changes in the salt content during the ripening period demonstrated varied statistical significants $(\mathrm{P}<0.01)$ and the salt content was higher in goat milk Tulum cheese $(\mathrm{P}<0.05)$ as was the Ash content $(\mathrm{P}<0.01)$. This could have been due to higher mineral matter and salt content in goat milk. Furthermore, different ash values in the ash analysis, as an indicator of mineral and salt content, could have resulted from the different titratable acidity and $\mathrm{pH}$ values, which affected the absorption of salt. After the 15th ripening day, water losses were insignificant for each cheese, and dry matter content was higher in cow milk Tulum cheese $(\mathrm{P}<0.01)$, especially due to the high fat content. Goat milk Tulum cheese had a higher total nitrogen content $(\mathrm{P}<0.05)$. Generally, total nitrogen content remained stable during the ripening period. The $\mathrm{pH}$ values of both cheeses were not the

Table 1. Compositional characteristics of cheese milk $(n=2)$.

\begin{tabular}{ccc}
\hline Characteristics & Cow milk & Goat milk \\
\hline Dry matter $\left(\mathrm{g} 100 \mathrm{~g} \mathrm{~g}^{-1}\right)$ & $11.80 \pm 0.17$ & $12.05 \pm 0.37$ \\
Fat $\left(\mathrm{g} 100 \mathrm{~g}^{-1}\right)$ & $3.50 \pm 0.10$ & $3.24 \pm 0.06$ \\
Protein $\left(\mathrm{g} 100 \mathrm{~g}^{-1}\right)$ & $3.12 \pm 0.09$ & $3.37 \pm 0.18$ \\
Ash $\left(\mathrm{g} 100 \mathrm{~g}^{-1}\right)$ & $0.80 \pm 0.03$ & $0.75 \pm 0.04$ \\
$\mathrm{pH}$ & $6.65 \pm 0.05$ & $6.71 \pm 0.03$ \\
Titratable acidity $(\%$ lactic acid $)$ & $0.16 \pm 0.02$ & $0.14 \pm 0.01$ \\
\hline
\end{tabular}




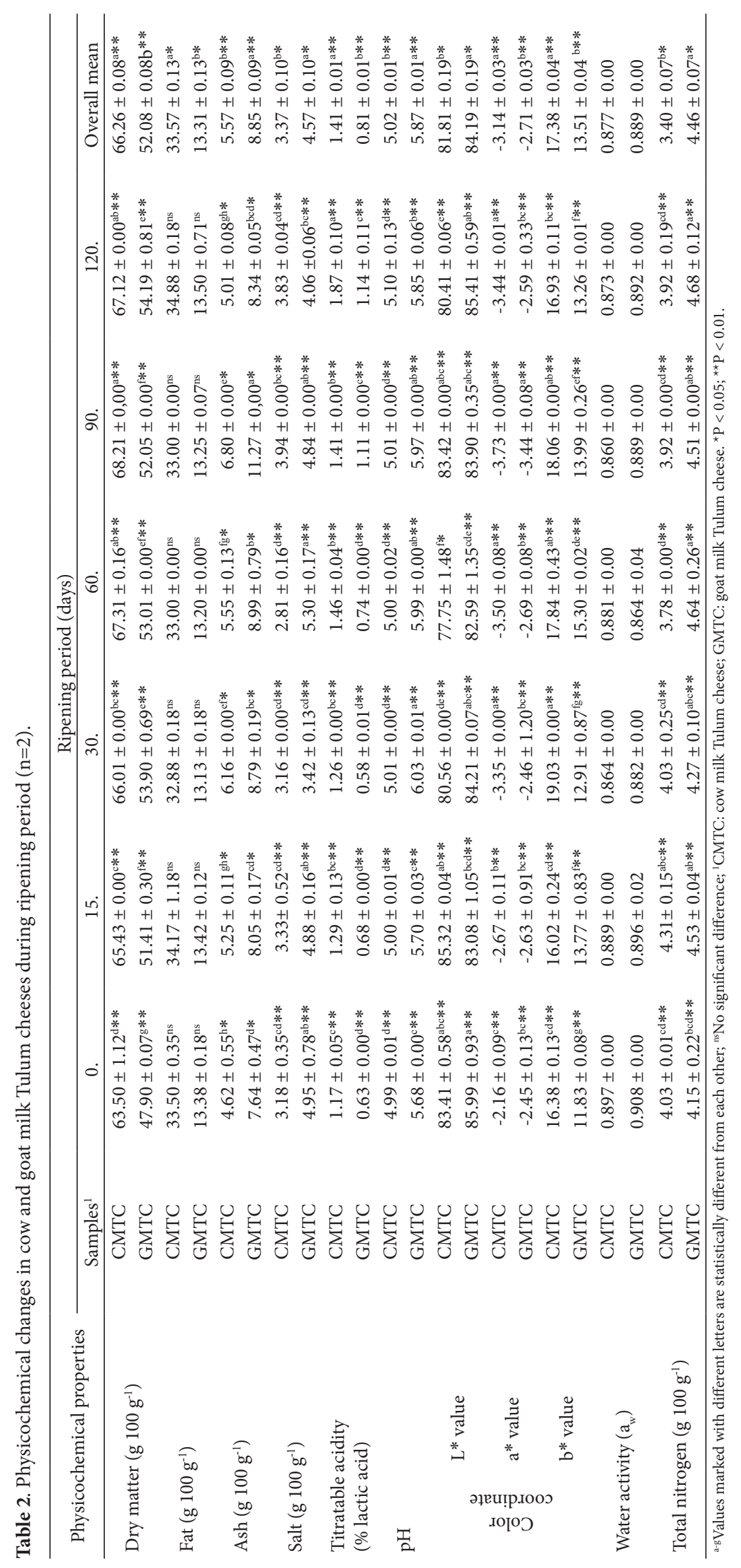


same $(\mathrm{P}<0.01)$, with the goat milk Tulum cheese having a higher $\mathrm{pH}$ value around 5.87. While the $\mathrm{pH}$ value of cow milk Tulum cheese was constant during the ripening period, in goat milk Tulum cheese it increased on the 30th ripening day. Alonso et al. (1987) reported that acid degradation performed by yeasts and molds, and amphoteric peptides and amino acids, which occurred by proteolysis at the progressive ripening days, brought about the increase of $\mathrm{pH}$ value. The titratable acidity was higher in cow milk Tulum cheese $(\mathrm{P}<0.01)$, and the highest titratable acidity in both cheeses was observed at the end of the ripening period $(\mathrm{P}<0.01)$.

No differences were found in the water activity of Tulum cheeses, but a reduction was determined in accordance with the initial water activity value during the ripening period. McSweeney (2004) reported that the water activity value fell as a result of the hydrolysis of the casein matrix by proteolysis, which took place during the cheese ripening. Goat milk Tulum cheese had a higher $\mathrm{L}^{*}$ value $(\mathrm{P}<0.01)$ that may have resulted due to the low content of $\beta$-carotene in goat milk, making it appear whiter in color. Values of $\mathrm{a}^{*}$ were negative for the Tulum cheeses. Cow milk Tulum cheese had a higher $\mathrm{a}^{*}$ value $(\mathrm{P}<0.01)$, which may be in consequence of high fat content and color pigments such as $\beta$-carotene in cow milk. Cow milk Tulum cheese was yellower $(\mathrm{P}<0.01)$ because of high fat content.

\subsection{Chromatographic profiles of Tulum cheese peptides by RP-HPLC}

The peptide profiles of the WSEs obtained from cow and goat milk Tulum cheeses changed with the progression of ripening days. Chromatographic peaks of the WSEs increased with the progression of days as shown in Figure 1 and 2. It was reported that hydrophilic peptides were generally determined between 20 - 40 retention times (Yoshida, 2004). Thus, as shown in Figure 1 and 2, the hydrophilic peptide content of goat milk Tulum cheeses was higher than that in cow milk Tulum cheeses. The amounts of all water-soluble peptides at the beginning of the ripening period were considerably poor. However, they increased with the advancement of ripening days $(\mathrm{P}<0.01)$. Sforza et al. (2012) reported that the formation of oligopeptides in Parmigiano-Reggiano cheeses showed parallelism with ripening days. Diezhandino et al. (2015) determined an increase in the peptide amount through the ripening days in Spanish blue cheese. Increment of the peak number during the ripening period was resulted from hydrolysis of peptides and proteins. Depending on the number of ripening days, a series of large and intermediate sized peptides derived from caseins began to occur due to plasmin, other proteolytic enzymes, microbial enzymes, and residual coagulant activity in the cheese. Afterward, these constituents converted to shorter peptides and amino acids by secondary microflora (Gupta et al., 2009).

The highest peak numbers were observed in WSEs from cow and goat milk Tulum cheeses on the 120th ripening day. The number of peaks were found to be significantly different upon comparing the cow and goat milk Tulum cheeses. WSEs acquired from goat milk Tulum cheese had higher number of peptide peaks in the ripening period, except on the 120th day. Raw cows' and goats' milk have the potential to a diverse bacterial population as reported previously (Alonso-Calleja et al., 2002; Quigley et al., 2011). Hence, these results can be indicative of the diversity of wild flora in the composition of raw milk. Pisanu et al. (2015) reported that the peptide profile differed in ripened sheep milk cheese, which was produced using raw and pasteurized milk. This was because raw milk had a higher content of bio-functional peptides.

\subsection{Antioxidative activity}

Inhibition results of DPPH radical demonstrated that the antioxidant activity increased with the progression of ripening days $(\mathrm{P}<0.01)$ for both the Tulum cheese samples (Table 3 ). Gupta et al. (2009) examined that DPPH inhibition (\%) of WSEs isolated from Cheddar cheese increased until 4 months as well. Abadía-García et al. (2013) determined an increase of

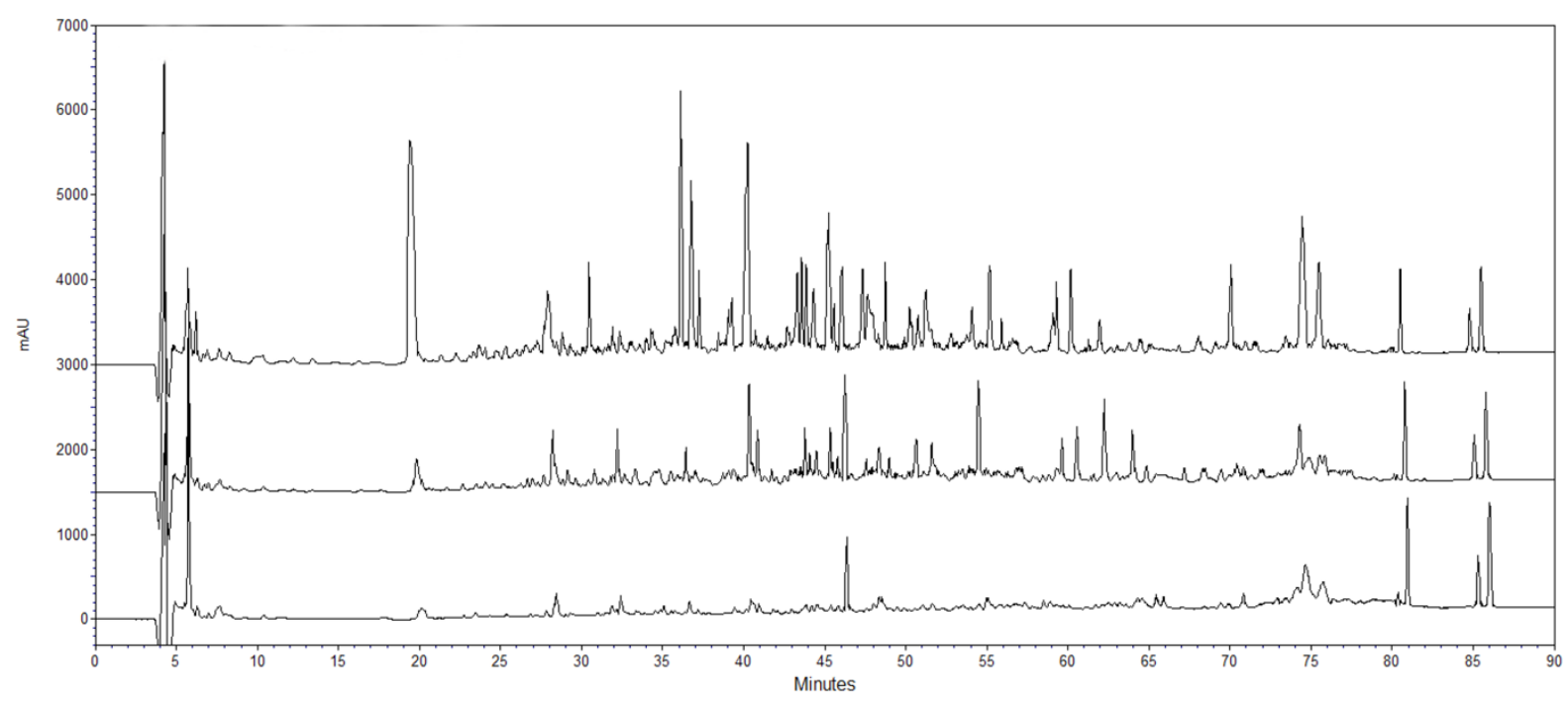

Figure 1. Peptide profiles of the WSEs of cow milk Tulum cheeses. Detection was at $214 \mathrm{~nm}$. Profiles were determined by reversed-phase chromatography using a Phenomenex Jupiter C18 column. Chromatogram results are given from the 0th, 60th, and 120 th days from bottom to top. 


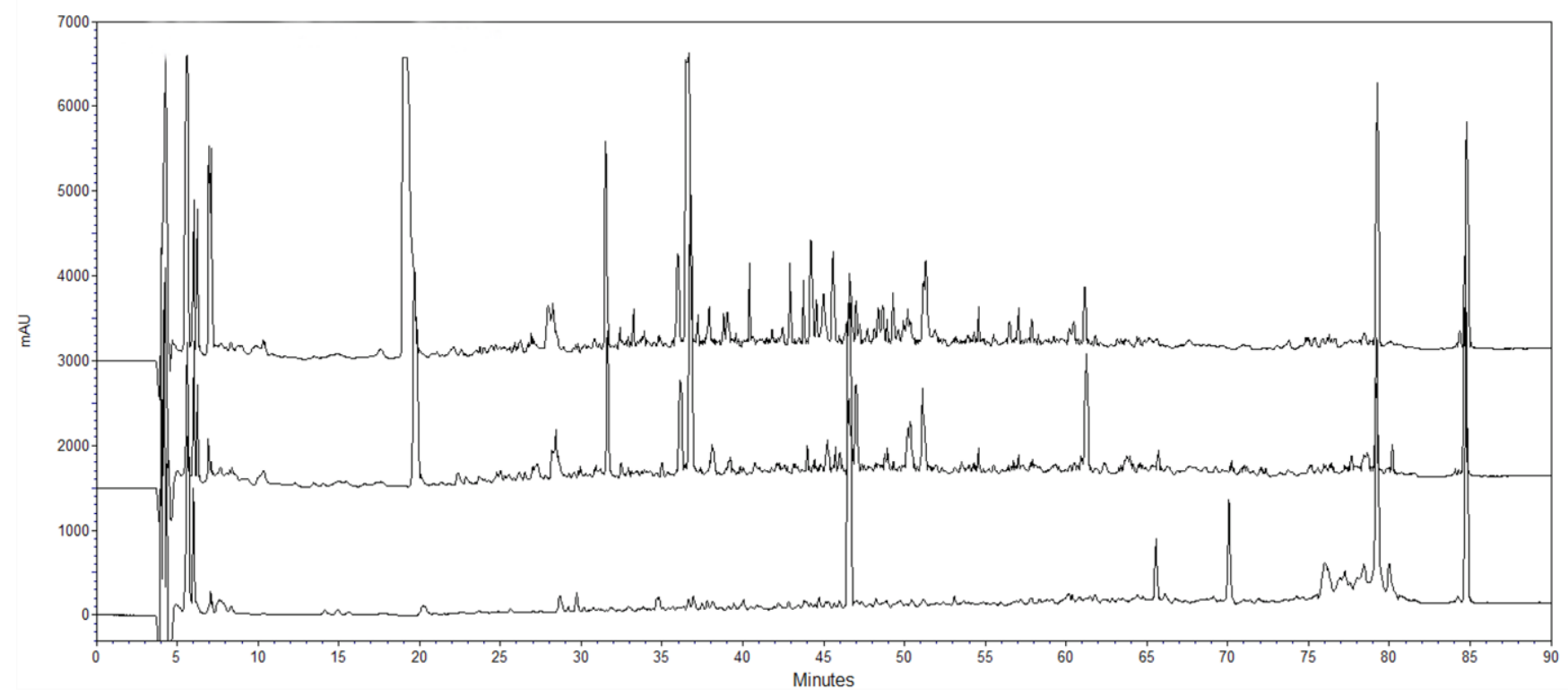

Figure 2. Peptide profiles of WSEs of goat milk Tulum cheeses. Detection was at $214 \mathrm{~nm}$. Profiles were determined by reversed-phase chromatography using a Phenomenex Jupiter C18 column. Chromatogram results are given from the 0th, 60th, and 120th days from bottom to top.

Table 3. Antioxidant and mineral binding properties of WSE obtained from cow and goat milk Tulum cheeses during ripening period ( $\mathrm{n}=2$ ).

\begin{tabular}{|c|c|c|c|c|}
\hline \multirow{3}{*}{ Ripening period (days) } & \multicolumn{2}{|c|}{ DPPH } & \multirow{2}{*}{\multicolumn{2}{|c|}{ Chelating activity (\%) }} \\
\hline & \multicolumn{2}{|c|}{ \% Inhibition } & & \\
\hline & CMTC & GMTC & CMTC & GMTC \\
\hline 0 & $13.25 \pm 1.56^{\text {c** }}$ & $21.58 \pm 2.04^{\mathrm{d} * *}$ & $4.68 \pm 0.04^{j \star *}$ & $22.20 \pm 0.04^{\mathrm{h} \star *}$ \\
\hline 30 & $18.41 \pm 1.37^{\mathrm{bc} * *}$ & $25.04 \pm 0.09^{\mathrm{bcd} * *}$ & $36.94 \pm 0.02^{\text {e**}}$ & $64.51 \pm 0.02^{b \star *}$ \\
\hline 60 & $20.94 \pm 3.37^{\mathrm{b} * *}$ & $27.50 \pm 0.71^{\mathrm{abc} * *}$ & $30.19 \pm 0.02^{g * *}$ & $65.99 \pm 0.02^{\mathrm{a} \star *}$ \\
\hline Overall mean & $20.34 \pm 0.70^{\mathrm{b} *}$ & $25.97 \pm 0.70^{\mathrm{a} \star}$ & $30.67 \pm 0.04^{\mathrm{b} * *}$ & $54.75 \pm 0.04^{\mathrm{a} * *}$ \\
\hline
\end{tabular}

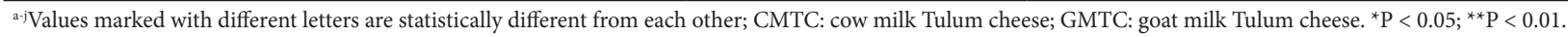

inhibition (\%) of DPPH radical with the increase in storage days in WSEs isolated from Cottage cheese. These results were caused by further proteolysis occurred in the ripening period. Timón et al. (2014) reported that the DPPH inhibition capacity of the WSEs isolated from Burgos-type cheese became higher as the peptide concentration increased.

Goat milk Tulum cheese had a higher antioxidant activity with regards to the DPPH method $(\mathrm{P}<0.05)$. This case could have been caused due to higher hydrophilic peptides content in goat milk Tulum cheese. According to the DPPH inhibition (\%), antioxidant activities of WSEs in cow and goat milk Tulum cheeses were higher than those observed in Himalayan cheese produced using raw buffalo milk (Mushtaq et al., 2015), and commercial Australian Cheddar cheeses (Pritchard et al., 2010).

\subsection{Mineral binding activity}

Table 3 presents values (\%) for the chelating activities of WSEs from cow and goat milk Tulum cheeses. Iron (II) chelating ability took place at distinct values for WSE samples during ripening period. The chelating activities of WSEs isolated from cow and goat milk Tulum cheeses were higher than Roquefort, Cerrillano, and Pecorine-type cheeses produced using sheep milk (Meira et al., 2012). Goat milk Tulum cheese had significantly higher chelating activity than cow milk Tulum cheese $(\mathrm{P}<0.01)$. The highest iron chelating activity of WSEs was observed in goat milk Tulum cheese on the 60th ripening day $(\mathrm{P}<0.01)$. After the 60th day, iron chelating activity of WSEs decreased in goat milk Tulum cheese $(\mathrm{P}<0.01)$. The changes observed in the chelating activity results of WSEs could be due to the fact that novel peptides with different functional properties were created by proteolysis, and the peptides having the chelating ability were hydrolyzed during the ripening period. Corrêa et al. (2011) asserted that the hydrolysis time had an inverse impact on $\mathrm{Fe}^{2+}$ binding ability of the WSEs, and longer hydrolysis time decreased metal chelation activity.

\subsection{Antimicrobial activity}

The ability of WSEs to inhibit the growth of Esherichia coli ATCC 25922, Listeria monocytogenes ATCC 7644, Staphylococcus auerus ATCC 25923, Clostridium perfringens ATCC 13124, 
Bacillus cereus ATCC 11778, and Salmonella typhimurium ATCC 14028 was investigated. An antimicrobial activity against Salmonella typhimurium ATCC 14028 was only observed on the 90th ripening day in goat milk Tulum cheese. The inhibition zone was measured as $44 \mathrm{~mm}$ and the zone was observed in a disk using $10 \mu \mathrm{L}$ of WSE.

Corrêa et al. (2011) determined antimicrobial activity against Bacillus cereus and Corynebacterium fimi in sheep caseinate hydrolysates for $3 \mathrm{~h}$ and the diameters of the inhibitory zones were measured as 9.3 and $11.5 \mathrm{~mm}$ respectively. In another study on Italian cheese varieties, Rizzello et al. (2005) detected antimicrobial activities against Lactobacillus sakei A15, Listeria innocua DSM 20649, Bacillus megaterium F6, and Escherichia coli K12 in WSEs obtained from Caprino del Piemonte (goat milk and no starter) and Crescenza cheeses (cow milk and freeze dried thermophilic starter), and the diameters of the inhibitory zones were determined between $3 \mathrm{~mm}-6 \mathrm{~mm}$ for indicator Lactobacillus sakei A15. Pritchard et al. (2010) identified antimicrobial activities against Escherichia coli ATCC 8739 and Bacillus cereus ATCC 11778 in WSEs isolated from Australian Cheddar cheese. Meira et al. (2012) examined no antimicrobial effect in WSEs obtained from ripened sheep cheeses. Rizzello et al. (2005) determined no antimicrobial activity in WSEs isolated from Fossa cheese produced with sheep milk as well. Generally, while antimicrobial activity against Bacillus strains (Gram-positive) was determined in many studies carried out using peptides isolated from cheese, antimicrobial activity against Salmonella typhimurium (Gram-negative) was identified in this study. In addition to this, the diameter of the inhibitory zone identified in this study was higher than the diameters of the inhibitory zones determined in the previous studies.

None of the WSEs obtained from cow milk Tulum cheese during the ripening period demonstrated antimicrobial activity against indicator microorganisms. Furthermore, antimicrobial activity of WSEs isolated from the goat milk Tulum cheese could not be observed during the ripening period, with the exception of the 90th day. It could have resulted from the changes in the peptidomics structure of the cheeses during the ripening period. When chromatographic results were compared, the most extensive hydrophobic peptide content was observed in the goat Tulum cheese on the 90th ripening day. Rizzello et al. (2005) identified antimicrobial activity in Caprino del Piemonte and Crescenza cheeses, which contained the majority of peptides in the hydrophobic site. However, they determined that none of the Parmigiano-Reggiano, Pecorino Romano, Fossa, and Caciocavallo cheeses, which contained abundant peptides in the hydrophilic site, showed antimicrobial activity.

Antimicrobial peptides derived from milk proteins have an inhibitory impact on a wide range of microorganisms, including pathogens and spoilage microorganisms (Corrêa et al., 2011). However, in this study, only Gram-negative bacteria was inhibited. Differences in the bacterial membrane compositions between Gram-positive and Gram-negative bacteria might have influenced the inhibition action and the bacterial specificity of the antimicrobial extract. This study has shown that goat milk Tulum cheese peptides displayed antimicrobial activity.

\section{Conclusion}

Consequently, the peptide profile of ripened cow and goat milk Tulum cheeses produced using raw milk demonstrated statistically significant differences $(\mathrm{P}<0.01)$. It was determined that the quantity of peptides in WSEs was higher in goat milk Tulum cheese. These different results were most likely appertaining to the alteration of raw milk constituents, such as microbial or proteolytic enzymes, and varieties of appropriate proteins that underwent enzymatic breakdown by proteolysis for the formation of the peptides during the cheese ripening. WSEs obtained from cow and goat milk Tulum cheeses presented antioxidant and mineral binding activities. In addition to this, WSEs from goat milk Tulum cheese showed antibacterial activity against Salmonella typhimurium ATCC 14028. Changes in the functional properties of cheese peptides were examined during the ripening period, and generally, the defined functional activities increased with the progression of ripening days. Goat milk Tulum cheese has been found to have higher bioactivity of functional peptides during the ripening period.

Several cheeses are still produced using raw milk; therefore, the use of goat milk in the cheese production may be more beneficial for health, in terms of diversity and functional activity of the bioactive components. It was determined that Tulum cheeses ripened for a long time was more healthful for consumers.

\section{Acknowledgements}

This research was taken from my master's thesis titled "Determination of some quality characteristics, contents and functional properties of bioactive peptides of Tulum cheeses produced by traditional method" and supported by Selcuk University Scientific Research Projects Coordinatorship (Project number: 14201033).

\section{References}

Abadía-García, L., Cardador, A., Campo, S. T. M., Arvízu, S. M., Castaño-Tostado, E., Regalado-González, C., García-Almendarez, B., \& Amaya-Llano, S. L. (2013). Influence of probiotic strains added to cottage cheese on generation of potentially antioxidant peptides, anti-listerial activity, and survival of probiotic microorganisms in simulated gastrointestinal conditions. International Dairy Journal, 33(2), 191-197. http://dx.doi.org/10.1016/j.idairyj.2013.04.005.

Akın, N. (2010). Temel peynir bilimi-I (1st ed.). Konya: Damla Ofset Press.

Alonso, L., Juárez, M., Ramose, M., \& Martín-Álvarez, P. J. (1987). Overall composition, nitrogen fractions and fat characteristics of Cabrales cheese during ripening. Zeitschrift fur Lebensmittel-Untersuchung und -Forschung, 185(6), 481-486. http://dx.doi.org/10.1007/BF01042813.

Alonso-Calleja, C., Carballo, J., Capita, R., Bernardo, A., \& GarcíaLópez, M. L. (2002). Changes in the microflora of Valdeteja raw goat's milk cheese throughout manufacturing and ripening. Lebensmittel-Wissenschaft + Technologie, 35(3), 222-232. http:// dx.doi.org/10.1006/fstl.2001.0842.

Association of Official Analytical Chemists - AOAC. (2000). Official methods of analysis of the Association of Official Analytical Chemists: nitrogen in cheese (16th ed., Method 33.7.12). Gaithersburg: AOAC.

Association of Official Analytical Chemists - AOAC. (2002). Official methods of analysis of the Association of Official Analytical Chemists: ash of cheese (Method 935.42). Gaithersburg: AOAC. 
Bauer, A. W., Kirby, W. M., Sherris, J. C., \& Turck, M. (1966). Antibiotic susceptibility testing by a standardized single disk method. American Journal of Clinical Pathology, 45(4), 493-496. PMid:5325707.

Bhandari, P., Kumar, N., Singh, B., \& Ahuja, P. S. (2010). Online HPLCDPPH method for antioxidant activity of Picrorhiza kurroa Royle ex Benth. and characterization of kutkoside by Ultra-Performance LC-electrospray ionization quadrupole time-of-flight mass spectrometry. Indian Journal of Experimental Biology, 48(3), 323328. PMid:21046989.

Corrêa, A. P. F., Daroit, D. J., Coelho, J., Meira, S. M., Lopes, F. C., Segalin, J., Risso, P. H., \& Brandelli, A. (2011). Antioxidant, antihypertensive and antimicrobial properties of ovine milk caseinate hydrolyzed with a microbial protease. Journal of the Science of Food and Agriculture, 91(12), 2247-2254. PMid:21560133.

Diezhandino, I., Fernández, D., González, L., McSweeney, P., \& Fresno, J. (2015). Microbiological, physico-chemical and proteolytic changes in a Spanish blue cheese during ripening (Valdeón cheese). Food Chemistry, 168, 134-141. PMid:25172692. http://dx.doi.org/10.1016/j. foodchem.2014.07.039.

Farkye, N. Y. (2004). Cheese technology. International Journal of Dairy Technology, 57(2-3), 91-98. http://dx.doi.org/10.1111/j.14710307.2004.00146.x.

Fox, P. (1963). Potentiometric determination of salt in cheese. Journal of Dairy Science, 46(7), 744-745. http://dx.doi.org/10.3168/jds. S0022-0302(63)89134-1.

Gupta, A., Mann, B., Kumar, R., \& Sangwan, R. B. (2009). Antioxidant activity of Cheddar cheeses at different stages of ripening. International Journal of Dairy Technology, 62(3), 339-347. http:// dx.doi.org/10.1111/j.1471-0307.2009.00509.x.

Haenlein, G. F. W., \& Caccese, R. (1984). Goat milk versus cow milk. In: G.F.W. Haenlein \& D. Ace (Eds.), Extension goat handbook. Washington: United States Department of Agriculture.

Haque, E., Chand, R., \& Kapila, S. (2008). Biofunctional properties of bioactive peptides of milk origin. Food Reviews International, 25(1), 28-43. http://dx.doi.org/10.1080/87559120802458198.

International Dairy Federation - IDF. (1982). Standart 4A: determination of the total solids content in cheese and processed cheese. Brussels.

International Organisation for Standardization - ISO. (2008). Cheese: determination of fat content - Van Gulik method (Standard 3433). Geneva.

Jenness, R. (1980). Composition and characteristics of goat milk: review 1968-1979. Journal of Dairy Science, 63(10), 1605-1630. http://dx.doi. org/10.3168/jds.S0022-0302(80)83125-0.

Kirk, S., \& Sawyer, R. (1991). Pearson's composition and analysis offoods. Harlow: Longman Group Ltd.

Korhonen, H., \& Pihlanto, A. (2006). Bioactive peptides: production and functionality. International Dairy Journal, 16(9), 945-960. http:// dx.doi.org/10.1016/j.idairyj.2005.10.012.

Kuchroo, C., \& Fox, P. (1982). Soluble nitrogen in cheddar cheese: comparison of extraction procedures. Milchwissenschaft $=$ Milk Science International, 37, 331-335.

Lang, K., \& Steinberg, M. (1980). Calculation of moisture content of a formulated food system to any given water activity. Journal of Food Science, 45(5), 1228-1230. http://dx.doi.org/10.1111/j.1365-2621.1980. tb06527.x.

McSweeney, P. L. (2004). Biochemistry of cheese ripening. International Journal of Dairy Technology, 57(2-3), 127-144. http://dx.doi. org/10.1111/j.1471-0307.2004.00147.x.

Meira, S. M. M., Daroit, D. J., Helfer, V. E., Corrêa, A. P. F., Segalin, J., Carro, S., \& Brandelli, A. (2012). Bioactive peptides in water-soluble extracts of ovine cheeses from Southern Brazil and Uruguay. Food Research International, 48(1), 322-329. http://dx.doi.org/10.1016/j. foodres.2012.05.009.

Minitab Inc. (1991). Minitab reference manual (Release 7.1). Pensilvânia: State College.

Mushtaq, M., Gani, A., Shetty, P. H., Masoodi, F., \& Ahmad, M. (2015). Himalayan cheese (Kalari/kradi): effect of different storage temperatures on its physicochemical, microbiological and antioxidant properties. Lebensmittel-Wissenschaft + Technologie, 63(2), 837-845. http://dx.doi.org/10.1016/j.lwt.2015.04.054.

Park, Y., \& Jin, Y. (1998). Proteolytic patterns of Caciotta and Monterey Jack hard goat milk cheeses as evaluated by SDS-PAGE and densitometric analyses. Small Ruminant Research, 28(3), 263-272. http://dx.doi.org/10.1016/S0921-4488(97)00092-8.

Park, Y., Juárez, M., Ramos, M., \& Haenlein, G. (2007). Physico-chemical characteristics of goat and sheep milk. Small Ruminant Research, 68(1), 88-113. http://dx.doi.org/10.1016/j.smallrumres.2006.09.013.

Pihlanto, A. (2006). Antioxidative peptides derived from milk proteins. International Dairy Journal, 16(11), 1306-1314. http://dx.doi. org/10.1016/j.idairyj.2006.06.005.

Pinho, O., Mendes, E., Alves, M., \& Ferreira, I. (2004). Chemical, physical, and sensorial characteristics of "Terrincho" ewe cheese: changes during ripening and intravarietal comparison. Journal of Dairy Science, 87(2), 249-257. PMid:14762067. http://dx.doi. org/10.3168/jds.S0022-0302(04)73163-X.

Pisanu, S., Pagnozzi, D., Pes, M., Pirisi, A., Roggio, T., Uzzau, S., \& Addis, M. F. (2015). Differences in the peptide profile of raw and pasteurised ovine milk cheese and implications for its bioactive potential. International Dairy Journal, 42, 26-33. http://dx.doi. org/10.1016/j.idairyj.2014.10.007.

Pritchard, S. R., Phillips, M., \& Kailasapathy, K. (2010). Identification of bioactive peptides in commercial Cheddar cheese. Food Research International, 43(5), 1545-1548. http://dx.doi.org/10.1016/j. foodres.2010.03.007.

Quigley, L., O’Sullivan, O., Beresford, T. P., Ross, R. P., Fitzgerald, G. F., \& Cotter, P. D. (2011). Molecular approaches to analysing the microbial composition of raw milk and raw milk cheese. International Journal of Food Microbiology, 150(2-3), 81-94. PMid:21868118. http://dx.doi.org/10.1016/j.ijfoodmicro.2011.08.001.

Raynal-Ljutovac, K., Park, Y., Gaucheron, F., \& Bouhallab, S. (2007). Heat stability and enzymatic modifications of goat and sheep milk. Small Ruminant Research, 68(1), 207-220. http://dx.doi.org/10.1016/j. smallrumres.2006.09.006.

Richardson, G. (1985). Standard methods for the examination of dairy products. Washington: American Public Health Association.

Rizzello, C. G., Losito, I., Gobbetti, M., Carbonara, T., Bari, M., \& Zambonin, P. (2005). Antibacterial activities of peptides from the water-soluble extracts of Italian cheese varieties. Journal of Dairy Science, 88(7), 2348-2360. PMid:15956298. http://dx.doi.org/10.3168/ jds.S0022-0302(05)72913-1.

Rutherfurd-Markwick, K. J., \& Moughan, P. J. (2005). Bioactive peptides derived from food. Journal of AOAC International, 88(3), 955-966. PMid:16001873.

Sforza, S., Cavatorta, V., Lambertini, F., Galaverna, G., Dossena, A., \& Marchelli, R. (2012). Cheese peptidomics: a detailed study on the evolution of the oligopeptide fraction in Parmigiano-Reggiano cheese from curd to 24 months of aging. Journal of Dairy Science, 95(7), 3514-3526. PMid:22720910. http://dx.doi.org/10.3168/jds.2011-5046. 
Sousa, M., Ardö, Y., \& McSweeney, P. (2001). Advances in the study of proteolysis during cheese ripening. International Dairy Journal, 11(4), 327-345. http://dx.doi.org/10.1016/S0958-6946(01)00062-0.

Tang, S., Kerry, J., Sheehan, D., \& Buckley, D. (2002). Antioxidative mechanisms of tea catechins in chicken meat systems. Food Chemistry, 76(1), 45-51. http://dx.doi.org/10.1016/S0308-8146(01)00248-5.

Timón, M. L., Parra, V., Otte, J., Broncano, J. M., \& Petrón, M. J. (2014). Identification of radical scavenging peptides $(<3 \mathrm{kDa})$ from Burgostype cheese. Lebensmittel-Wissenschaft + Technologie, 57(1), 359-365. http://dx.doi.org/10.1016/j.lwt.2014.01.020.
Topçu, A., \& Saldamli, I. (2006). Proteolytical, chemical, textural and sensorial changes during the ripening of Turkish white cheese made of pasteurized cows' milk. International Journal of Food Properties, 9(4), 665-678. http://dx.doi.org/10.1080/10942910500542238.

Turkish Statistical Institute. (2014). The amount of Tulum cheese production. Ankara: TUIK.

Yoshida, T. (2004). Peptide separation by hydrophilic-interaction chromatography: a review. Journal of Biochemical and Biophysical Methods, 60(3), 265-280. PMid:15345295. http://dx.doi.org/10.1016/j. jbbm.2004.01.006. 